\title{
Teknologi Voltametri HDME, Sensitif Deteksi Asam Urat dalam Tubuh
}

\author{
Rain Kihara Boangmanalu, Fachreza Erdi Pratama, Afina Dwi Rachmawati*, Bella Puteri Irinda \\ Program Studi Sarjana Farmasi, Fakultas Farmasi, Universitas Padjadjaran, Sumedang, 45363 \\ email: afinadwirachmawati@yahoo.co.id
}

\begin{abstract}
Abstrak :
Pada masyarakat sekarang ini, pemeriksaan asam urat sudah menjadi hal yang biasa dan sering dilakukan untuk mengetahui kondisi kesehatan karena asam urat menjadi salah satu faktor penting dalam metabolisme tubuh. Tingkat konsentrasi asam urat dapat mengindikasikan atau dikaitkan dengan gout, kegemukan, diabetes, kolesterol, tekanan darah, penyakit ginjal dan penyakit hati. Teknik pemeriksaan asam urat sangat beragam dengan tingkat akurasi dan sensivitas yang berbeda-beda pula. Metode voltametri dengan Hanging Mercury Drop Electrode (HMDE) memiliki potensi pengembangan terbaik dari metode voltametri lain misalnya glassy carbon electrode yang memiliki kelemahan yaitu selektivitas kurang pada sampel urin yang mengandung asam askorbat (vitamin C).
\end{abstract}

Keyword : Asam urat, voltametri, hanging mercury drop electrode(HMDE)

\section{Outline}

- Pendahuluan

- Deteksi Asam Urat

- Stripping Voltammetry

- Hanging Drop Mercury Electrode (HDME)

- Kesimpulan

\section{Pendahuluan}

Pemeriksaan kadar asam urat dalam tubuh sudah menjadi hal yang biasa dan sering dilakukan untuk mengetahui kondisi kesehatan karena asam urat menjadi salah satu faktor penting dalam metabolisme tubuh. Senyawa asam urat mempunyai peranan dan fungsi yang penting dalam proses metabolisme tubuh. Namun jika senyawa asam urat dalam tubuh memiliki kadar yang tidak normal maka akan menyebabkan tubuh terserang penyakit dengan gejala-gejala tertentu. Konsentrasi asam urat yang tinggi biasa dihubungkan dengan penyakit gout. Kenaikan konsentrasi asam urat dalam tubuh juga meningkatkan resiko penyakit kardiovaskular. Teknik pemeriksaan asam urat sangat beragam dengan tingkat akurasi dan sensivitas yang berbeda-beda pula.

\section{Deteksi Asam Urat}

Pemeriksaan asam urat oleh para biomedis menjadi perhatian utama karena senyawa ini memiliki peranan penting dalam metabolisme tubuh. Konsentrasi abnormal dalam tubuh menunjukkan terjadinya gejala beberapa penyakit dalam tubuh seperti diabetes, kolesterol tinggi, tekanan darah tinggi, penyakit ginal dan penyakit hati. 
Metode pemeriksaan yang sudah umum dipakai saat ini adalah menggunakan asam fosfotungstat yang kemudian dianalisis dengan spektrofotometri. Salah satu kelemahan metode ini adalah perlakuan sampel yang rumit sehingga membutuhkan waktu pemeriksaan yang cukup lama.

Dalam dunia medis, konsentrasi asam urat dalam tubuh umumnya dihitung dengan metode spektrofotometri dan pendekatan enzim menggunakan enzim uricase. Namun telah ada metode-metode lain yang bisa digunakan untuk mendeteksi kadar asam urat dalam tubuh, salah satunya yaitu dengan menggunakan metode stripping voltammetry.

Voltametri terdiri dari analisis identifikasi keberadaan asam urat dan analisis penentuan jumlah asam urat dengan cara kerja :

1. Melihat analit elektroaktif yang mempunyai potensial spesifik untuk identifikasi keberadaan asam urat

2. Penentuan jumlah asam urat dilakukan dengan mengukur besarnya arus difusi yang timbul karena konsentrasi analit yang sebanding dengan arus difusi.

\section{Stripping Voltammetry}

Stripping voltammetry merupakan metode yang sangat efektif dalam analisis senyawa dalam jumlah atau konsentrasi kecil. Agar analisis dapat berjalan, ada 3 parameter penting, yaitu: potensial deposisi, waktu deposisi, dan kecepatan pengadukan. Untuk meningkatkan sensitivitas metode ini, dapat dilakukan cara :

1. Melakukan reaksi elektrolisis pada sampel

2. Saat reaksi elektrolisis selesai, terjadi Pelarutan kembali sampel untuk kemudian dioksidasi, pada saat itulah proses pengukuran dilakukan.

Dari voltamogram, maka didapatkan hasil analisis berdasarkan komponen (keberadaan senyawa) dan kuantitas. Data analisis keberadaan senyawa diperoleh dari potensial standar yang didapatkan. Sampel mempunyai potensial standar spesifik. Data analisis secara kuantitas diperoleh dengan besar arus atau luas area voltamogram yang sama dengan konsentrasi sampel dalam larutan. Semakin besar arus maka semakin besar konsentrasi asam urat dalam suatu larutan.

\section{Hanging Drop Mercury Electrode (HDME)}

Salah satu metode yang sedang dikembangkan dan memiliki potensi dengan tingkat selektivitas dan sensitivitas yang tinggi yaitu metode voltametri Hanging Mercury Drop Electrode (HMDE). Metode ini cukup menarik karena dibanding teknik voltametri lain yaitu glassy carbon electrode, metode voltametri HDME dapat dipakai untuk analisis dalam sampel darah dan urin bersama-sama dengan elektroaktif lain misalnya asam askorbat (vitamin C).

Pengembangan metode ini diharapkan dapat menghasilkan alternatif analisis asam urat dengan keunggulan dibandingkan metode yang ada saat ini lebih cepat, mudah, dan sensitive dan batas deteksi yang rendah. 
HDME ini merupakan suatu alat dalam suatu percobaan dengan stripping voltammetry dan analisis voltametri (Banica, 2000). Instrumen yang diperlukan untuk analisis pada voltametri yaitu prosesor unit dan elektroda. Elektrode yang digunakan yaitu elektroda kerja, elektroda pembanding, dan elektroda counter. Untuk elektroda kerja, banyak elektroda yang dapat digunakan yaitu glassy carbon electrode (GCE), elektroda emas, elelktroda grafit, dan mercury drop electrode (MDE). Elektroda kerja merupakan elektroda tempat terjadinya reaksi reduksi dan oksidasi untuk asam urat dalam sampel.

Permasalahan dalam analisis asam urat pada sampel urin yang mengandung asam askorbat (vitamin c) adalah kedua senyawa yang sulit dipisahkan dengan menggunakan glassy carbon electrode sehingga selektivitas kurang. Dengan menggunakan metode voltametri yaitu Hanging Mercury Drop Electrode (HMDE) memiliki potensi pengembangan terbaik dan juga dapat menjadi salah satu metode dengan selektivitas dan sensitivitas yang tinggi.

\section{Kesimpulan}

Asam urat telah menjadi hal yang tidak asing lagi bagi seluruh populasi di seluruh dunia. Pengukuran kadar asam urat dalam darah sangat penting untuk mengetahui adanya perubahan kadar asam urat dalam tubuh. Kadar asam urat yang tinggi dalam darah berpotensi menimbulkan penyakit lain seperti kolesterol, gout, dan kenaikan tekanan darah.

Penggunaan metode voltametri dengan hanging mercury drop electrode sebagai alat untuk mengukur kadar asam urat dalam tubuh dapat dikatakan sangat efektif dan sensitif karena dapat membaca kadar asam urat dalam tubuh meskipun dalam jumlah yang sangat sedikit.

\section{Daftar Pustaka}

[1] Chen, J. C., Chung, H. H., Hsu, C. T., Tsai, D. M., Kumar, A. S., dan Zen, J. M. 2005. A Disposable Single-Use Electrochemical Sensor For The Detection Of Uric Acid In Human Whole Blood. Journal of Sensors Dan Actuators B Vol 1:10 hal. 364.

[2] Khasanah, Miratul, Supriyanto, Garden dan Handajani, Usreg Sri. 2006. Deteksi Sensitif Asam Urat Secara Stripping Voltammetry menggunakan Hanging Mercury Drop Electrode (HMDE). Surabaya : Perpustakaan Universitas Airlangga.

[3] Zare, H. R., Rajabzedeh, N., dan Ardakani, M. M. 2006. Voltammetric Studies of an Oracet Blue Modified Glassy Carbon Electrode and Its Application For The Simultaneous Determination of Dopamine, Ascorbic Acid And Uric Acid. Journal of Electroanalytical Chemistry Vol. $1: 1$.

[4] Banica, Florinel Gabriel. 2000. A Simple Hanging Mercury Drop Electrode. Journal of Chemical Education. Vol 77: 98-100. 